\title{
EFL Students' Satisfaction with the College English Education in the MOOC: An Empirical Study
}

\author{
Tao Nie \\ School of International Studies \\ Zhejiang University \\ Hangzhou, China \\ tnie@zju.edu.cn
}

\author{
Jie $\mathrm{Hu}^{*}$ \\ School of International Studies \\ Zhejiang University \\ Hangzhou, China \\ huj@zju.edu.cn \\ *Corresponding author
}

\begin{abstract}
The College English course has already become an essential part of the higher education in China. MOOC, as the most advanced teaching mode, has attracted the attention from educators. Since students are the subjects and beneficiaries of the course, it is important to research on students' satisfaction with the College English course based on the MOOC. This research investigates students' satisfaction with the College English course in the MOOC from dimensions of teacher, course, interaction and learner. In this study, 125 undergraduates taking the College English course in D University were selected. Questionnaire surveys and interviews were conducted according to students' satisfaction. The study shows that students were generally satisfied with the College English course in the MOOC environment. Students' most satisfaction was founded in the course dimension, whereas the least satisfaction in the learner dimension. This study proves the significance of students' satisfaction to the improvement and reform of the College English course and proposes suggestions for the improvement of the College English course quality based on MOOC. This research paper was partially adopted from the graduation thesis.
\end{abstract}

Keywords—students' satisfaction; MOOC; College English course

\section{INTRODUCTION}

The College English course has become the most popular course with more than 6 million college students taking this compulsory course every year in higher education in the mainland China [1]. With this huge educational market, MOOC, as the most advanced teaching mode, has positively engaged in the College English course since 2013, and has dramatically been spread in more than 460 institutions and universities in the mainland China [2]. Although such huge of teaching and learning resources have been invested to improve the English language proficiency of EFL students, whether students are satisfied with the course is an essential question to be answered and suggested for policy-makers and educators for further educational reform with the largest population of EFL learners in the world, which may provide a reference for considerations and reflections of English language proficiency learning in the MOOC context for worldwide EFL educators and learners.

The MOOC has been recognized as the internationalized open-learning opportunity with free access to an unlimited

The National Social Science Foundation of China (Ref. 12XYY012), Zhejiang University Education Foundation, and the Research Fund fo Teaching and Research Development of Liberal Arts Teachers in Zhejiang University. number of learners [3]. The widespread use of this novel teaching and learning pattern is attributed to its openness with flexible time and location, high quality with qualified teachers, and student-centered learning pattern with active learners, which help to address the increasing needs of technologically effective and efficient education resources of the College English course in China [4] [5]. MOOC has also been emphasized as the essential information technological method to promote the College English education in the latest policy, the College English Teaching Guidance in China [6]

Several previous research from ESL/EFL language education in the MOOC environment has provided new insights into teaching methods [2] [4], course materials [7] [8]. Few studies, however, have explored students' satisfaction with ESL/EFL English language courses in the MOOC context. Students are key participants in the English language courses [5], and their attitudes toward the class should be carefully valued as they not only influence students' motivations and academic performances, but also shape the design and delivery of ESL/EFL courses and affect the quality of teaching in general [5]. However, educational researchers and MOOC producers usually focus more on the big data provided by MOOC platforms and the learning analyses, to evaluate students' interactions with the teachers, course contents, and peers, which are not sufficient for them to fully understand students' experiences with the MOOC [8]. In other research, students' satisfaction is only taken as one of the measuring instrument to evaluate the quality of the distance education but without cause analyses [2].

Therefore, the investigation into students' satisfaction and the systematical analysis of impact factors can guide future policy-making, teaching practices and investment plans in English language learning at the higher education level. Thus, this study aims to solve the following research questions: 1) What are college students' overall impressions of the College English course in the MOOC environment? 2) What are the specific reasons influencing students' satisfaction with the College English course in the MOOC environment? 3) What are the suggestions to improve students' satisfaction with the College English course in the MOOC environment? 


\section{MethodOLOGY}

\section{A. Instruments}

This case study adopted the qualitative and quantitative educational approaches. A questionnaire and an interview were constructed in this research. The questionnaire used in the research is adopted from the Course Experience Questionnaire and the Student Satisfaction Questionnaire in the EFL Classroom Environment with acceptable and reasonable validity and reliability $(\mathrm{KMO}=0.947)$.

\section{B. Participants}

The participants of this research were 125 undergraduates who have finished the 16 weeks of College English course studies with the MOOC at D university in China. D University has launched the College English course on Icourse as the most authentic MOOC platform in China for more than three years and owns the largest population of students taking the College English course with the MOOC. Not only has MOOC been used as an effective teaching instrument of the College English course for years, but also sufficient teaching and learning experiences and relatively mature and reliable MOOC courses can be accessed in this top-tier university. In the 20172018 academic year, more than 9,000 college students from the whole country have enrolled in the online College English course provided by this university. It was accounted that more than $30 \%$ enroll students are from one single university, which is the course organizer institution, D University. Thus, students from D University are ideal participants for this study to explore their satisfaction with the MOOC of English language proficiency education.

\section{Data collection and data analysis}

Data were collected from the regular College English course of MOOC sessions. It took approximately 20 minutes for each student to complete the paper-based questionnaire right after the session. 11 volunteer students engaged in the semi-structured interview to provide suggestions of MOOC enhancement after answering the questionnaire. The data were analyzed by SPSS 25 and discussions were accordingly conducted.

\section{RESULTS}

The norm of students' satisfaction is characterized by the teacher dimension, course dimension, interaction dimension and learner dimension. The teacher dimension includes the items regarding with teaching style and the support offered by teachers. The course dimension contains the course preparation, the usefulness and the effectiveness of the course. The interaction dimension consists of the teacher-student and student-student interactions reflected from the course. The learner dimension evaluates students' self-efficacy, learning anxiety and self-regulation.

\section{A. The Teacher Dimension}

The results from Table 1 indicate that students were generally satisfied with the course in the teacher dimension. Three items (items 3, 12 and 15) were in the near-optimal status with a mean score over 4 , which presented that students were highly satisfied with the opportunities to discuss, teachers' teaching attitudes, as well as the effect of English language immersion mode offered by teachers with MOOC, respectively. These phenomena might result from teachers' active and supportive consciousness. However, the results of items that related to the teaching style (items 1, 2, 5, 6 and 14) were lower than the general mean score, in contrast, which showed the conflict between teachers' intentions and the realistic situation in class. The statistical results of items 7 and 9 indicate that students were willing to have a more interesting and thought-provoking class, which needed teachers' concise preparations in the pre-class stage. The std. deviation showed that there was no extreme outlier in the teacher dimension.

TABLE I. THE TEACHER DIMENSION OF STUDENTS' SATISFACTION

\begin{tabular}{|c|c|c|c|}
\hline Item No. & Content & Mean & $\begin{array}{c}\text { Std. } \\
\text { Deviation }\end{array}$ \\
\hline \multicolumn{2}{|c|}{ Teacher dimension } & 3.69 & .62 \\
\hline Item 1 & $\begin{array}{l}\text { The instructor is passionate during } \\
\text { English language MOOC class. }\end{array}$ & 3.63 & .92 \\
\hline Item 2 & $\begin{array}{l}\text { The atmosphere in English } \\
\text { language classroom is enjoyable. }\end{array}$ & 3.26 & .99 \\
\hline Item 3 & $\begin{array}{l}\text { The instructor gives us plenty } \\
\text { opportunities to present our ideas } \\
\text { and opinions in English language } \\
\text { class }\end{array}$ & 4.05 & .81 \\
\hline Item 4 & $\begin{array}{l}\text { The instructor applies novel and } \\
\text { different teaching methods. }\end{array}$ & 3.94 & .85 \\
\hline Item 5 & $\begin{array}{l}\text { The instructor is humorous during } \\
\text { English language class }\end{array}$ & 3.42 & .88 \\
\hline Item 6 & $\begin{array}{l}\text { The teacher is humorous when } \\
\text { talking with us. }\end{array}$ & 3.48 & .99 \\
\hline Item 7 & $\begin{array}{l}\text { The instructor always stimulates my } \\
\text { thought and interest. }\end{array}$ & 3.67 & .98 \\
\hline Item 8 & $\begin{array}{l}\text { The instructor provides assistance } \\
\text { in academic-related areas. }\end{array}$ & 3.53 & .98 \\
\hline Item 9 & $\begin{array}{l}\text { Materials and activities of this } \\
\text { course are interesting to me. }\end{array}$ & 3.66 & .96 \\
\hline Item 12 & $\begin{array}{l}\text { I appreciate the instructor's positive } \\
\text { attitude towards life. }\end{array}$ & 4.03 & .90 \\
\hline Item 14 & $\begin{array}{l}\text { The teacher often uses some self- } \\
\text { disclosure when talking with us. }\end{array}$ & 3.57 & 1.01 \\
\hline Item 15 & $\begin{array}{l}\text { It is helpful to enhance my English } \\
\text { language ability by teaching in } \\
\text { English in the class. }\end{array}$ & 4.11 & .83 \\
\hline
\end{tabular}

According to the interview in this dimension, the teacher's performance of the class organization was professional but the teaching style was relatively inflexible. With the application of the MOOC, although teachers intentionally constructed the high-quality teaching to meet students' needs, students had different individual expectations of teaching, which were not satisfied with, in fact. Additionally, these new audiences of the MOOC admitted that the mode of the MOOC teaching was novel, which was also shown in item 4 , but the contents could not attract their attention for a relatively long term, such as 20 minutes of screen reading or video learning.

\section{B. The Course Dimension}

The statistical results of Table 2 show that students were satisfied with the course dimension items with the highest mean score of 3.83 among four dimensions. This dimension explored the new study pattern (item 10), the course preparation (item 17), the usefulness (items 18 and 19) and the effectiveness (items 11, 16, 20, 21 and 30) of the course. Students were mostly satisfied with the course preparation 
(item 17), which ranked as the highest mean score (mean=4.18) in this dimension and amongst the whole 33 items. Items 18 and 19 imply that participants were satisfied with the usefulness of the course, with the mean of 3.93 and 4.14, respectively; however, the results related to the course effectiveness (items 11, 16, 20, 21 and 30) ranked as the medium level, which were $15 \%$ lower than that of the course usefulness. One possible reason for this polarization is that students considered that the materials were out-of-date for them to make any improvement. Although students understood the importance of the College English course participation, they preferred to spend time in learning with more interesting and updated materials. No extreme outlier was found in this dimension, according to the std. deviation.

TABLE II. The COURSE DimENSION OF STUDENT S' SATISFACTION

\begin{tabular}{|c|l|c|c|}
\hline Item No. & \multicolumn{1}{|c|}{ Content } & Mean & $\begin{array}{c}\text { Std. } \\
\text { Deviation }\end{array}$ \\
\hline Course dimension & 3.83 & .66 \\
\hline Item 10 & MOOC is interesting to me. & 3.75 & 1.00 \\
\hline Item 11 & MOOC can attract my attention. & 3.64 & 1.04 \\
\hline Item 13 & $\begin{array}{l}\text { The instructor always reacts timely to } \\
\text { my problem if I have any. }\end{array}$ & 3.98 & .93 \\
\hline Item 16 & $\begin{array}{l}\text { English language class learning can } \\
\text { promote my English language } \\
\text { proficiency and capability. }\end{array}$ & 3.86 & .93 \\
\hline Item 17 & $\begin{array}{l}\text { The teaching materials are well- } \\
\text { organized and presentable. }\end{array}$ & 4.18 & .74 \\
\hline Item 18 & $\begin{array}{l}\text { MOOC is helpful in imp roving my } \\
\text { English language proficiency. }\end{array}$ & 3.93 & .85 \\
\hline Item 19 & $\begin{array}{l}\text { Different forms of listening training } \\
\text { can improve my English listening and } \\
\text { speaking skills. }\end{array}$ & 4.14 & .77 \\
\hline Item 20 & $\begin{array}{l}\text { This class is helpful in promoting my } \\
\text { English speaking skills. }\end{array}$ & 3.77 & .93 \\
\hline Item 21 & $\begin{array}{l}\text { Teaching by using MOOC enhances } \\
\text { our learning efficiency. }\end{array}$ & 3.55 & 1.00 \\
\hline Item 30 & MOOC is in line with our needs. & 3.54 & .91 \\
\hline
\end{tabular}

For interviewees, it was no doubt that the College English course in the MOOC environment was useful. They could at least improve their listening and speaking skills during the courses, such as by listening and imitating the native English speakers' pronunciation, but the quality of the MOOC should be further improved. Some students thought that improving the MOOC design could be an effective way to increase their satisfaction, for example, allowing more time for students to think in depth during the course. Two of the interviewees directly said that they did not like using the MOOC in class, as they did not feel any improvement in the effectiveness of learning with piles of key points in a short MOOC video.

\section{The Interaction Dimension}

As is shown in Table 3 , the interaction dimension (mean=3.61) did not reach the satisfactory level for students. Items 22 and 23 with the highest mean (3.64) in this dimension suggested that students would learn and finish the assignments through group cooperation. In contrast, the satisfaction level of item 31, which related to the usual communication, was very low (mean $=3.30$ ). This could be possibly explained that students were less likely to communicate with peers, except for the necessary communication in the course. The result of item 25 (mean=3.30) showed that there was also a lack of oral presentations, by which students and teachers could exchange or reflect their ideas. The results of this dimension implied that most students did not have connections with each other until they were required to so, such as the completion of group work, so that the satisfaction of interaction dimension was less than the expectations. The std. deviation showed that the means of interaction dimension were stable.

TABLE III. THE INTERACTION DIMENSION OF STUDENTS' SATISFACTION

\begin{tabular}{|c|c|c|c|}
\hline Item No. & Content & Mean & $\begin{array}{c}\text { Std. } \\
\text { Deviation }\end{array}$ \\
\hline \multicolumn{2}{|c|}{ Interaction dimension } & 3.61 & .69 \\
\hline Item 22 & $\begin{array}{l}\text { I have made great progress through } \\
\text { cooperating with my classmates in } \\
\text { English courses. }\end{array}$ & 3.64 & .91 \\
\hline Item 23 & $\begin{array}{l}\text { I often work with other students to } \\
\text { complete the tasks assigned by the } \\
\text { teacher }\end{array}$ & 3.64 & .93 \\
\hline Item 25 & $\begin{array}{l}\text { Oral presentations are required in each } \\
\text { semester, which also serve as a tool to } \\
\text { gauge students' performance in the } \\
\text { final exam. }\end{array}$ & 3.30 & .95 \\
\hline Item 31 & $\begin{array}{l}\text { I often exchange my learning } \\
\text { experience and methods with other } \\
\text { classmates. }\end{array}$ & 3.30 & .90 \\
\hline
\end{tabular}

Most participants in the interview were not satisfied with the interactions in class. Some students held that the so-called "mute English" learning mode made it hard to take place any interaction. Some of those who wanted to participate class activities might be discouraged, especially when peers kept silent in class. Since they were not even acquaintances in daily life, those students had no motivation to make efforts to interact with others. In addition, most interviewees agreed that teachers had made efforts to encourage students to engage the active interaction in class, but students were too shy to present themselves.

\section{The learner dimension}

The results of Table 4 show that students were not satisfied with the learning dimension, with the lowest general mean of 3.59 among the four dimensions. Items 26, 28, 29 could be grouped to evaluate students' foreign language learning anxiety in the College English course in the MOOC. Although students did feel secure in the class, with the highest mean of 3.70 (item 28 ) in this dimension, students were anxious about the class as the mean of items 26 and 28 were lower than the general mean. The satisfaction with item 33 was the lowest (2.62) in this dimension and the whole 33 items, presenting that the distraction was the most serious problem in the College English course with the MOOC. Students were not able to focus on the MOOC from time to time. This is possibly because that the pace of the MOOC teaching was too fast for many students to follow (item 24), not only in teachers' speaking speed, but also in the course arrangement. According to the std. deviation, there was no extreme outlier in the results of the learner dimension. 
TABLE IV. THE LEARNER DIMENSION OF STUDENTS' SATISFACTION

\begin{tabular}{|c|l|c|c|}
\hline $\begin{array}{c}\text { Item } \\
\text { No. }\end{array}$ & \multicolumn{1}{|c|}{ Content } & Mean & $\begin{array}{c}\text { Std } \\
\text { Deviation }\end{array}$ \\
\hline \multicolumn{2}{|c|}{ Learner dimension } & 3.59 & .65 \\
\hline Item 24 & MOOC is too fast for me to follow. & 3.30 & 1.24 \\
\hline Item 26 & $\begin{array}{l}\text { I feel uncomfortable if asked to } \\
\text { participate in classroom activities. }\end{array}$ & 3.30 & .96 \\
\hline Item 27 & $\begin{array}{l}\text { Teaching activities proceed too fast for } \\
\text { me to follow. }\end{array}$ & 3.56 & .99 \\
\hline Item 28 & $\begin{array}{l}\text { I feel secure in English language } \\
\text { lassroom }\end{array}$ & 3.70 & .48 \\
\hline Item 29 & $\begin{array}{l}\text { I tend to be absent-minded easily in } \\
\text { English language classes. }\end{array}$ & 3.12 & 1.01 \\
\hline Item 32 & $\begin{array}{l}\text { I can have a good grasp of what we } \\
\text { learn in the classroom. }\end{array}$ & 3.50 & .82 \\
\hline Item 33 & $\begin{array}{l}\text { It is easy to get distracted when } \\
\text { watching MOOC. }\end{array}$ & 2.62 & 1.10 \\
\hline
\end{tabular}

Some interviewees indicated that the reason for the distraction in class was that the knowledge could be absorbed properly if they read the texts on their own. Some added that this was an issue of individual learning style which might not only happen in the English language classes. It might also because that having a smart phone at hand overrode the motivation to learn. These led to students' nervousness in the participation of activities, for they were not able to keep the course pace with teachers' instructions.

\section{CONCLUSION}

The present research investigated cross-disciplined ESL/EFL college students' satisfaction with College English course in the MOOC pattern in four dimensions and with four affective factors. The research findings suggest that students were generally satisfied with College English course in the MOOC environment, and with the most satisfaction with the course, whereas the least satisfaction with students themselves in the learner dimension, which needed urgent improvement with the suitable MOOC for participants.

The least satisfactions were recognized in the learner dimension, and students are suggested to change the unfavorable situation by themselves; however, the more effective and efficient ways to improve this phenomenon are regarded with the good course organization and professional support from teachers. Teachers are suggested to change their roles from the instructor, knowledge imparter and achievement assessor to the class organizer and facilitator [5]. Through establishing a friendly teacher-student relationship and creating a relaxing class atmosphere, the interactions may be enhanced if teachers encourage students' active engagement of the course. In addition, teaching contents should have the close connection to the themes that students are familiar with and are suitable to. The MOOC activities and materials adopted by teachers should not only help to expand students' knowledge, but also increase students' confidence and motivation with more interactions and thought-provoking contents.

It is also important for colleges or institutions to meet the differences of individuals' English language proficiency and their learning styles with adaptive, personalized and suitable teaching methods or learning styles. The tailored English language educational pattern may help students concentrate on the MOOC learning, the least satisfaction of MOOC by students, with their own needs, in order to increase the satisfaction with the College English course in the future study.

A few aspects in the present study are in need of improvement: Firstly, the scale of this study is not large enough, which may affect the representation of a larger group of target participants, because that other samples may produce different results. Secondly, since there is no in-depth analysis of the data to formulate corresponding evaluation indicators and evaluation models, the research is in need of further exploration in this aspect. Therefore, future research can be conducted from these two aspects for the more reliable research.

\section{ACKNOWLEDGMENT}

The authors would like to appreciate the anonymous reviewers for valuable comments on this paper.

\section{REFERENCES}

[1] National Bureau of Statistics of China, "National data," Online at http://data.stats.gov.cn/search.htm in Chinese.

[2] Z. Li, "The impact and inspiration of the College English education model by MOOCs," in Advances in Economics, Business and Management Research, Vol. 48, 2017, pp. 5.

[3] T. R. Liyanagunawardena, A. A. Adams, and S. A. Williams, "MOOCs: A systematic study of the published literature 20082012,” in The International Review of Research in Open and Distance Learning, vol. 14, 2014, pp. 202-227.

[4] B. Wang, "The College English teaching reform based on MOOC,” in English Language Teaching, vol. 10, 2017, pp. 1922.

[5] L. Fang, "A tentative study on MOOC-based strategies of college students' self-learning ability," in International Conference on P2p, Parallel, Grid, Cloud and Internet Computing, 2016, pp. 865-867.

[6] Ministry of education, "College English Teaching Guidance”, unpublished.

[7] J. Reich, "Rebooting MOOC research," in Science, vol. 347, 2015, pp. 34-35.

[8] Y. Anzai and K. Akahori, "What are the dimensions of language learning with MOOCs for English learners?” in International Conference on Web-Based Learning, 2016, pp. 118-122. 